\title{
John James McIntosh Shaw, M.C., M.A., M.D., F.R.C.S.E.
}

"AND he said to me as we walked across the fields, 'To-night we shall be at war, to-morrow we begin to pay the price which war demands, and it will be in the dark currency of death." " This quotation came to my mind when I heard that J. J. M. Shaw was dead. The Edinburgh Medical School has been called upon at an early stage to pay an item in the grim tally, and it has been in the loss of one who could ill be spared, a man who was accomplishing a great service in enhancing the reputation of his school and in fashioning the direction of its future. Shaw laid down his task while in his fifty-fourth year, an age when, as some would say, life is at its best-an age which looks back on years full of happy memories, of friends, of difficulties overcome, of things accomplished, of work well done; an age which looks forward to the days which lie ahead with hope that the future holds further achievements ere the sun sets. In our friend's case the curtain has fallen in life's midday; the future and its promised bright visions have been denied to him, but we who knew him can look back upon the part he played, and, as we record it, we pay tribute to its sincerity and its worth. Were I asked to choose the motto which best describes the impulse of Shaw's being my choice would fall upon the single word "Service," and surely there could be no finer testimony to his memory. From his student days, when first I knew him, until the hour when his spirit passed into the Egyptian night, his life was one of service to others, of devotion to such things as are worthy and of good report. There are few aspects of our social, academic, and professional activities which have not benefited from his interest, his wisdom, and his genius. As an undergraduate he played a leading part in the life and development of the University Union; he occupied the honourable position of President, an indication of his popularity and of the esteem with which his fellow-students regarded him. Athletics claimed his interest, and again the recognition of his merits placed him in the Presidentship of the University Athletic Club. He entered the "Battery," and within the space of a few years the Bombardier had become a Lieutenant. So far as I am aware the trilogy is unique, and it surely has its significance, for it bespeaks the faculty of leadership, the ability to rise to the top wherever his lot might be cast. It was no jealous sense of power which placed him in these high places, it was his own urge to serve, 
and the recognition by his fellows that here was one upon whose word and judgment they might rely.

In the War of 1914-I 8 there arrived an opportunity which brought out some of his finest qualities. His devotion to duty was unswerving, his reputation as an indefatigable worker placed him in centres where pressure was most heavy, and amidst these supreme demands he pursued his task with a courage and a cheerfulness which made light of danger and difficulty. It was a fitting recognition of his merits when he was decorated with the Military Cross and the Croix de Guerre.

When peace came it was characteristic that Shaw should turn his thoughts and energies to reconstruction-the act of service in its best and highest form. The spheres in which he laboured are too numerous to mention individually, but one of them stands out supreme-the grim yet pathetic field of plastic surgery. He worked here with diligence and success, and his reward was to bring happiness, confidence, and selfrespect to men whose forms and features had been disfigured by the ravages of war.

In later years he became one of our most successful medical administrators. He was responsible for the creation of the Cancer Control Organisation in south-eastern Scotland, he occupied positions of high responsibility in the National Radium Trust, the Radium Commission, and the Scottish Cancer Advisory Committee. He took the keenest interest in all that concerned the treatment of malignant disease, and had he lived he would have seen in all probability the fulfilment of his highest ambition, the establishment of a Cancer Hospital and Research Institute in this city.

Amidst his many professional activities he was not forgetful of his former interests in University social life. The Union, the Athletic Club, the Settlement, and the Graduates' Association-with each of these he kept in touch, indeed he did more, he gave unstintingly of his time and energy in order that they might flourish.

Claims such as these might seem sufficient, and yet they were not all. Shaw was a surgeon of the first rank, a teacher of recognised distinction, a tireless investigator in the search after knowledge.

Is it surprising that we mourn his passing? We shall not easily look upon his like again, and the most fitting monument to his memory is what men are saying about him-" He spent his life in service to others."

He was elected a Fellow in I93I, and died "On Active Service" in Egypt in September I940. 